\title{
Religions and the Challenge for Social Transformation
}

Eiko Hanaoka*

\section{Abstract}

In this paper I discuss the new possibility of social transformation by religion in order to save the global nihilistic situation in the contemporary world because of the modern technology which neglected human dignity in all over the world since the Industrial Revolution started from England in the latter half of the 18th Century. Such possibility by religion can be realized, in my view, by "the way of walking" on the ground of "self-awareness", where each person realizes the great death of egoistic ego and is aware of the true self, which is common to each of all nature, which awareness then results in the faith in God as action, God who is non-substantial and has no peculiar nature of its own. Such religion could be found in the religion and the philosophy of religion advocated by A. N. Whitehead and K. Nishida.

Keywords: Religion as the way of walking, Self-awareness, Nihilism, Medium like eternal object, Mediumless mediation

\section{Religion and God in A. N. Whitehead and K. Nishida}

\section{A) Religion \\ K. Nishida, Japan's first original philosopher, says that "religion is an}

* Professor Emeritus of Osaka Prefecture University, Kyoto, Japan; hana9@khiro.jp 
event of the soul"1 in the field of absolute nothingness, and the core of religion are "compassion, sincerity or loyalty ${ }^{2}$ in the field of absolute nothingness, and philosophy is the explanation of religion. ${ }^{3}$ A.N. Whitehead thinks that "the primary religious virtue is sincerity, a penetrating sincerity" 4 and religion is "worldloyalty." 5 The world-loyalty can be understood as the loyalty of God to the world and simultaneously as the loyalty of the world, and this includes loyalty of each individual to God. This worldloyalty therefore consists in the oneness of God and world in their loyalty. Philosophy in Nishida is understood as "explanation of religion," 6 as reflection on religion. Philosophy in Whitehead is the expression of a coherent cosmology based upon the notions of " system", "process", "creative advance into novelty," 7 "an interpretation of the religious experience of mankind" 8 and the "elucidation of the ultimate integral experience " $(P R, 208)$.

Religion in Whitehead and Nishida is very similar, in that both philosophers look upon religion as sincerity or loyalty. The reason being that in Nishida sincerity or loyalty also consists in sincerity and loyalty of God, as non-substantial absolute nothingness, to the world and simultaneously sincerity and loyalty of the world, to God, in that in God as absolute nothingness the world and each individual are absolutely contradictory oneness. At first glance, Whiteheadian thinking seems to cover a wider ground than Nishida's philosophy. However, Nishida explains both the

${ }^{1}$ Shinichi Hisamatsu called the true self, which is common to each of all nature, "formless self". Cf. Shinichi Hisamatsu's Works, Vol. 3, Risosha Press $1976,460$.

${ }^{2}$ Kitaro Nishida: Last writings-Nothingness and the Religious Worldview $(=L R)$ trans. David A. Dilworth, Honolulu: University of Hawaii Press, $1987,47$.

${ }^{3}$ K Nishida: K. Nishida's Works, Bd. 11, Last Writings, 47.

${ }^{4}$ A. N. Whitehead: Religion in the Making (RM), New York: Fordham University Press, 2005, 15, 60.

${ }^{5}$ A. N. Whitehead, Religion in the Making, 60.

${ }^{6}$ Nishida: LW, 48.

${ }^{7}$ A. N. Whitehead: Process and Reality $(=P R)$, corrected edition, ed. David R. Griffin and D. W. Sherburne, The Free Press, Macmillan Publishers, New York 1929, 128.

8 PR, 167. 
humanities and natural science from "pure experience," 9 as religious experience. Nishida therefore covers not only the interpretation of religious experience, but also provides a coherent cosmology and elucidation of the ultimate integral experience. In regard to these areas, Nishida and Whitehead are thinking along rather similar lines. The essential differences, however, are the different approaches towards understanding of the field and medium. First the "field" 10 of Nishida's philosophy of absolute nothingness is looked upon as a non-substantial God. Contrariwise, the field in Whitehead is indirectly taken as an eternal object which is the idea as the form of absolute nothingness, namely as absolute infinite openness. Both men found, independently of each other, their suggestion in the concept of Plato's "chora" in the Timaios, and each of them advocated his own original and creative thought. On the one hand, Nishida deepened Plato's chora to the nonsubstantial field of absolute nothingness as action, and founded the philosophy of absolute nothingness. On the other hand, Whitehead took Plato's chora as an eternal object, understood as the idea that is the form of chora. In Whitehead, the field as Plato's chora is the common field where all lives can live ${ }^{11}$ and he established "organic philosophy".

The paradigm now, as the framework of life, culture and thinking common to all times and places seems to be being and nothingness, namely relative being, relative nothingness, absolute being, nihil and absolute nothingness. ${ }^{12}$ Absolute nothingness advocated by Nishida can be understood as "interdependent originality" (Japanese: engi, 縁起) as in the words of the Buddha (463-383 B. C.), or as "emptiness", as Ryuju has it (Sanskrit: Nagarjuna; in Japanese 龍樹, Ryuju, ca.150-ca.250 A. D.), in that Nishida superficially philosophized it, as he said. Absolute nothingness subsumes these

${ }^{9} \mathrm{~K}$. Nishida: An Inquiry into the Good, translated by Masao Abe and Christopher Ives, Yale University Press, New Haven and London: 1990, $\mathrm{xxx}, \& 3$.

${ }^{10}$ K. Nishida's Works, Band 10, Iwanami Press 1965, 241.

11 A. N. Whitehead: Adventures of Ideas (=AI), Collier Macmillan Publishers, London 1967, 187.

12 Eiko Hanaoka: Zen and Christianity, From the standpoint of absolute nothingness, Maruzen Press 2008, 103. 
other four paradigms. The reason being that absolute nothingness negates its own standpoint as agape and compassion and supports other four standpoints by other paradigms with agape as divine love and compassion. When absolute nothingness tries to support the standpoints by negating its own standpoint, resulting in zero, then absolute nothingness as action cannot but negate the standpoint of zero, and then it comes forth to the action. In this case agape and compassion pour forth. Absolute nothingness as absolute infinite openness is understood as the world of zero, if seen from an objective standpoint. However, it is filled with agape and compassion, if seen from the standpoint of the field of absolute nothingness.

While the standpoint of Nishida's absolute nothingness endlessly continues the double negation, the standpoint of the eternal object in Whitehead can be seen, taking the conclusion in advance, understood as an idea ${ }^{13}$ as form of Nishida's "field of absolute nothingness". The reason being that both Whitehead and Nishida, independent of each other, took suggestion from the field (Greek: chora) in Plato's Timaios, as mentioned above. In Whitehead the field (chora) is understood as the common field, in which all natural events are together, as the receptacle in unity, as we find it in his Adventures of Ideas. ${ }^{14}$ The difference concerning the field is that for Whitehead the field acts as eternal object, as an idea, an idea that is the form of, as it were, Nishida's field of absolute nothingness. Whitehead's ultimate categories are creativity, the one and the many; their cores consist of actual entity, of which all things-including God-are composed. Actual entity in Whitehead's organic philosophy is regarded as the final reality, and eternal object is taken for an idea as form of-so to speak-Nishida's field of absolute nothingness, ${ }^{15}$ as said above, although eternal object is not as deeply inquired into as it is in Nishida's field of absolute nothingness. However, in Whiteheadian philosophy the

${ }^{13}$ Eiko Hanaoka: Zen and Christianity- kirisutokyo-to-bukkyo-o megutte (The Origin of Zen and Christianity- Zen as the manifestation of the original life), Tozai-reisei-bunko 4, Nunburusha-Press 2010, 146, 152, 157, 160.

14 AI, 187.

15 Eiko Hanaoka: The Origin of Zen and Christianity, 146. 
presentational immediacy in direct experience in concrescence is connected with givenness (=data) as causal efficacy and in this connection Whiteheadian symbolic reference consists in the perception. In this understanding, causal efficacy acts as medium. In Whiteheadian philosophy, the eternal object as negative prehension acts as medium in the concrescence in the process from the many to the one with creativity. However, the difference between mediation without medium in Nishida and the medium in Whitehead, namely the difference of the reality in itself in the former and processional and simultaneously punctual reality as eternal object in the latter is not essential. The reason being that Nishida advocated the philosophy of self-awareness on the basis of feeling and will in the field of absolute nothingness, in that he starts out from "pure experience,"16 while the backbone of Whiteheadian philosophy is feeling. Moreover, Whitehead's term 'prehension' is the "appropriation of some elements in the universe to be components in the real internal constitution of results," 17 and positive prehension is seen as feeling, while negative prehension is regarded as conceptual feeling, the givenness of which is eternal object. Through the eternal object all arbitrary actualization is excluded. Namely, the ground of his organic philosophy consists in feeling as positive prehension and negative prehension, the givenness (=data) of which is the eternal object. From these facts the philosophy of self-awareness on the basis of feeling and will in Nishida and the organic philosophy of on the ground of feeling in Whitehead are very similar in spite of the difference between mediation of reality in itself as the field of absolute nothingness and medium as eternal object.

Now, in spite of the difference between Nishida's field of absolute nothingness and eternal object as the medium between the field of absolute nothingness and the actual world in Whitehead, Nishida's philosophy as explanation of religion and Whiteheadian philosophy as interpretation of religion on the basis of nonsubstantial feeling and will can be understood as philosophy of self-awareness, grounded on sincerity, or loyalty.

${ }^{16}$ K. Nishida: An inquiry into the good, 146.

17 PR, 231. 


\section{B) God}

In religion, salvation of each individual by God, Buddha or the transcendent is in general included. The ego by the nature of each individual changes into "existence "(ek-sistere) ${ }^{18}$ as breaking from the ego through the breakdown by love, death etc., and existence then changes into "life" 19 by falling into boredom, anxiety or despair, in that existence cannot find its own support like God. However, philosophy of life cannot but be deepened to the philosophy of true self, the core of which is the religion of selfawareness ${ }^{20}$ of the true self, ${ }^{21}$ in that the philosophy of life is characterized by staying only in immanence without living in the absolutely contradictory self-identity of immanence and transcendence.

Now, "the philosophy of self-awareness" can be the explanation or interpretation of the "religion of self-awareness", as far as philosophy can be understood as explanation and interpretation of religion, like in Whitehead and Nishida. If so, then God in Whitehead and Nishida must be inquired into. In Nishida, absolute nothingness as double negation which continues endlessly, namely non-substantial action as double negation of its own standpoint is

18 The etymological Latin of existence is ek-sistere, as M. Heidegger showed. The meaning of existence is, according to this etymology, to be out of ego.

${ }^{19}$ In the history of philosophy the standpoint of the individual was established by Rene Descartes' (1596-1650) "cogito ergo sum", and then by Kant (1724-1804) the dignity of personality as the aim in itself was established. While the concept of existence was surely established by Sören Kierkegaard (1813-1855), "philosophy of life", which was much deepened than "existence", was begun with Nietzsche and deepened by Bergson, Dilthey, Simmel and so on.

${ }^{20}$ In the 21st century the religion and the philosophy on the basis of selfawareness of true self and the world are postulated, which subsumes the philosophy of ego, existence, life and true self.

${ }^{21}$ The philosophy of self-awareness of true "self" was already inquired by mysticism in Eckhart (1260-1329), S. Kierkegaard and M. Heidegger. However, the philosophy of self-awareness of both "self and world" was established by the Kyoto school of philosophy (=K. Nishida, Tanabe Hajime, Keiji Nishitani) for the first time. 
looked upon as God. God as absolute nothingness in Nishida is understood as Buddha-nature, and the self-nature of each self is regarded as oneness with the Buddha-nature as non-selfness (=selfnature, in Japanese: mujishou, 無自性). God, Buddha, and self of each person therefore are in essence non-selfness, and therefore oneness, with Buddha-nature.

God in Whitehead was created simultaneously with each of all nature by creativity as one of three ultimate categories, namely creativity, the many, and the one. Moreover, God was created as an actual entity like each of all nature. However, God in Whitehead, as is generally known, consists in three natures: primordial nature, consequent nature, and superjective nature. The primordial nature of God is "free, complete, primordial, eternal, actually deficient and unconscious" (PR, 345). The consequent nature of God is determined, incomplete, consequent, everlasting, fully actual, and conscious. 22 The superjective nature is the "character of the pragmatic value of his specific satisfaction qualifying the transcendent creativity in the various temporal instances." 23 The primordial nature of God is "concrescence of unity of conceptual feelings, including among their data all eternal objects"( $P R, 87-88)$. The superjective nature of God consists in the ground of eternal object, and eternal objects require God in the same degree. The reason being that "an eternal object abstracts from all determinate actual entities including even God" (PR, 256). God in Whitehead is, so to speak, the ground of all nature, in that God acts together with eternal object, although God in it was created at the same time with each of all nature. The reason in detail being that the symbolic reference gives rise to the concrescence of causal efficacy as givenness (=data) in the past tradition with the presentational immediacy.

However, God as absolute nothingness in Nishida and God as ground of all nature in Whitehead, acting with eternal object as medium between God and world are very similar in spite of the difference between mediation and medium. The world as definition

23 PR, 88. 
or event (German: Ereignis ${ }^{24}$ ) by or from absolute nothingness and the individual being in the mutual definition between world and individual in itself are oneness with Nishida's God as absolute nothingness in reverse coincidence, as Nishida says. In Whitehead also God and world, therefore God and individual because of the world consisting of each and every individual, are in oneness only through the action of eternal object as medium.

The five reversibility's between God and world in the following items advocated by Whitehead coincide with Nishida's thinking, as based on the way of thinking in Buddhism. God and the world are mutually identical:

a. Concerning to be permanent and fluent (in Nishida: form or matter is non-substantial (=is empty). Emptiness is identical with matter.);

b. Concerning to be one and many (in Nishida: One is all and all is one.);

c. Concerning to be actual eminently (in Nishida: birth and death of beings is nirvana (=enlightenment.) ;

d. Concerning to be imminent and transcendent (in Nishida: the present is the eternal, although the relation between the self of human beings and God consists in inverse correspondence.)

Whitehead also mentions the reversibility between God and the world, that God creates the world and that the world creates God. This fact, however, does not coincide with Nishida's thinking. Since in Nishida, God is absolute nothingness as reality in itself as double negation in absolute presence, while in Whitehead God with three natures first acts with eternal object as medium between the field of absolute nothingness (=chora) and the actual, real world. However, in spite of the difference in

${ }^{24}$ The world as "the definition of the field of absolute nothingness" can be compared with the "Ereignis" from the being in itself to the beings in M. Heidegger. However, the difference between them is as follows: In Hisamatsu agape and compassion spring from the field of absolute nothingness, but in Heidegger agape and compassion from the being in itself are not stressed. 
understanding the relation between God and world, the concept of "loyalty" or "sincerity" as the core of religion is common to both thinkers.

Nietzsche (1844-1900) formally understood that the foundation of Christianity is loyalty (in German: Wahrhaftigkeit), and he negated it, since loyalty he understood to be the will to power "of weak people". But loyalty in both Whitehead and Nishida is a loyalty different from that negated by Nietzsche. In the kind of loyalty criticized and negated by Nietzsche we cannot find the kind of loyalty concerning the oneness of God and world, God and individual on the basis of feeling and will, in self-awareness. Nietzsche thinks not from the standpoint of God-man, but from the viewpoint of man-God. From such view Nietzsche cannot find loyalty on the part of God.

Now, religion in Whitehead and Nishida is different from the traditional, only substantial, religion, namely religion on the ground of self-awareness of the true self and the world in the field of absolute nothingness advocated by Nishida, and religion on the ground of feeling together with the action of eternal object as negative prehension until now, these differ from traditional understanding of religion on the basis of objective, intellectual religion in the following main ten points. ${ }^{25}$

Religion in both philosophers is

a. Considered from the origin of dualities and polarities. E. g. from the concrescence of rationality and experience, from the action of the substantial and the non-substantial;

b. Changed into the religion of absolutely contradictory selfidentical self-awareness of the oneness of self and world in the true self as "formless self";

c. Changed into religion in openness as the point where the horizontal dimension crosses the vertical dimension, where

25 E. Hanaoka: The problem of environment and nature through the philosophy of A. N. Whitehead and Nishida, in Process Thought, No. 5, The Japan Society for Process Studies, 2012, September, 61-70. 
heaven and earth have the same root, "all things are one body;"26

d. Changed, in their way of thinking, from subjective logic applied since Aristotle(384-322 B.C.) into predicative logic;

e. Changed into a way of thinking in harmony between the humanities and natural science, which is in harmony with the paradigm of absolute nothingness, like the theory of relativity, indeterminacy principle, the quantum theory, the discovery of Higgs boson in July 2012 (published by CERN in Europe), the product of induced pluripotent stem cells(=iPS) through initialization by Shinya Yamanaka;

f. Changed into harmony with nature, the etymology of which means "to open of itself" (German: von sich her aufgehen), as M. Heidegger says; ${ }^{27}$

g. Founded on the ground of feeling and will; intellect then is established upon them;

h. Established on the ground of the action of creativity in continuity of discontinuation, consisting of punctual coincidence as a moment between time and eternity;

i. Changed into harmony and peace among genus, species and individual, away from the opposite relation: war and strife;

j. Changed into the self-awareness of responsibility, the need of dialogue among the various religions and the sinconsciousness in self and world.

\section{The Challenge for Social Transformation}

European traditional and metaphysical religions believing in a substantial God, an eternal, universal, unchangeable, only personal God, are now falling into nihilism, in that only the eternal, universal, and unchangeable transcendent was made much of, and daily life was neglected. People in today's world therefore have a

${ }^{26}$ Hekigansyu, the 40th rule, Daizo Press, Tokyo 1982, 184.

27 E. Hanaoka: Zen and Christianity, 384f. 
tendency to be unable to find meaning, significance, aim, and value in their lives. In view of this understanding, the challenges for social transformation through the above mentioned 10 points should be met as follows.

Re (1): Duality or Polarity in the way of thinking about religion is represented by materialism and idealism. Religion in materialism will be represented by mammonism and idolatry. However, matter cannot become the ultimate concern in salvation of the human soul, as Paul Tillich (1886-1965) says ${ }^{28}$ on the one hand .The reason being that matter cannot be ultimate, since it decays with time. Religion in idealism will be represented by Christianity and German idealism. However, they will fall on the other hand into nihilism, in that daily life was neglected, as Nietzsche said. God was looked upon as vanished, in that extraordinary phenomena of nature and the prevalence of epidemics were often given rise to. On the contrary A. N. Whitehead and K. Nishida felt religion of loyalty or sincerity as the origin of polarities. This is the greatest challenge to overcome contemporary nihilism.

Re (2): In the unity of the relation between genus, species and individual like in Whiteheadian and Nishida's religion, freedom, equality, and divine love as agape are realized against the traditional religion on the basis of a standpoint only eternal, universal, and unchangeable, by subsuming inorganic substances, plants, and animals as the natural resources for human beings.

Re (3): When, on the crossroad, the secular horizontal way of thinking on the immanent level changes into thinking on the vertical way of thinking in the transcendental dimension, a new view of history gives rise to discontinual continuity, consisting of each moment (in Greek: kairos) in the stream of time (in Greek: aion).

Re (4): When the subjective logic since Aristotle changes into predicative logic, feeling and will become more important than intellect. The reason being that the way of thinking only by intellect is merely objective, abstract, and substantial, but that on the ground

28 On Tillich's "ultimate concern" cf. Systematische Theologie, Evangelisches Verlagswerk, Stuttgart 1956: Band I, $14 f$. 
of feeling and will it -is not just intellectual, but also subjective, concrete, and non-substantial, deepened by self-awareness of self and world. With this sea-change the ego can begin and proceed on its way to the true self, through the stages of existence, life and nihil.

Re (5): The changing of the relation natural science/humanities, currently marked as opposites, will make possible a non-opposite, harmonious, relationship. The reason being that natural science developed not only through the desire to promote peace between humankind and all nature, but also through desire for power, money, honour, likewise, through intellectual violence and demonic technology producing nuclear and hydrogen weaponry, not to mention accidents at nuclear power plants, e.g. Three Mile Island in 1979, Chernobyl in 1986, and Fukushima in March 2011.

Re (6): Recovery of the Greek and Latin etymology of "nature" (in Greek: physis, un-close from itself. In Latin: natura, from nasci, to be born and the core of things) having changed from the nature created by God to a nature contaminated and exploited by humankind, etymological understanding makes possible recovery of the whole personality of each person, estranged by others, and its own being.

Re (7): By changing to the superiority of feeling and will over intellect in Whitehead, truth, beauty, adventure and peace ${ }^{29}$ can be looked upon as the core of future civilization, and in Nishida "absolute love," 30 which is God of the ground of each person, embracing that which opposes itself, ${ }^{31}$ is regarded as most important. It must be added here that the origin of the evaluation of feeling and beauty can be found in Critique of the Power of Judgement by Immanuel Kant (1724-1804).

Re (8): In that creativity acts in the continuity of discontinuity of the punctual moment, like in Augustine (354-430), S. Kierkegaard (1813-1855), P. Tillich, A. N. Whitehead and K. Nishida, in which

\footnotetext{
${ }^{29}$ A. N. Whitehead: AI, 255.

${ }^{30}$ K. Nishida: Last Writings, 100.

${ }^{31}$ K. Nishida: Last Writings 100.
} 
time and eternity are in oneness, actual daily life may be lived creatively instead of only hoping to live in the beyond.

Re (9): In absolute infinite openness as absolute nothingness like in Nishida and in the action with eternal object like in Whitehead, totalitarianism, racism and dictatorial attitudes on the level of genus, species, and individual can change into peace on the basis of harmony, beauty and love as agape.

Re 10: Ethics of dialogue like in Martin Buber (1878-1965) ${ }^{32}$ and in the philosophy of responsibility like in Hans Jonas (1903-1993) 33 can be applied, instead of headstrong traditions with traditional authority, irresponsible command etc. M. Buber was Jewish Austrian and H. Jonas was Jewish German. Both of them therefore would seem to have thorough knowledge of God in "hayatology," 34 namely God as action or as event.

Now, in dialogue and responsibility in the present world, consciousness not only of people's own internal sin, before WW II, but also consciousness of external sin of the world after the second war must be emphasized, with regard to bombardment with nuclear devices, thermonuclear tests and accidents at nuclear power plants. For the longest time, ever since the redemption of biblical Adam and Eve, internal consciousness of one's own sins was stressed as self-awareness. But after World War II we must simultaneously emphasize sin-consciousness of the world that is external sin-consciousness. Without external sin-consciousness of the world our world, this planet, will be rendered hazardous through radioactive contamination and radioactive waste. To avoid this ruin of the planet, each person must cast off the ego towards existence, the stage of existence must rotate towards life, and the stage of life must be reborn as true self through physio-spiritual discipline, as exemplified in Japanese archery, Japanese fencing, the

32 M. Buber: Gottesfinsternis-Mit einer Entgegnung von C. G. Jung, Lambert Schneider Verlag, Stuttgart 1994.

${ }^{33}$ H. Jonas: Das Prinzip für die technologische Zivilization, Insel Verlag, Frankfurt am Main 1979.

34 On "God" as "hayah" (=I will be that I will be, Ex. 3, 14), cf. Eiko Hanaoka, Zen and Christianity, 290, 371-373. 
Ryukyuan art of self-defense etc., through sports as self-discipline, as art, through meditatively invoking the name of Amida Buddha, through intoning Christian prayer, through meditation as religious discipline on the one hand. However, to protect the earth and our descendents from nuclear contamination, each person must always have the external sin-consciousness of the world. Selfawareness of the world always realizes as self in each person.

\section{Religion and the Challenge for Social Transportation}

The aim of this treatise is to make clear that religion in the contemporary world, to be in a state to change society, must have both sides of the self-awareness of the true self and the world, by direct action of absolute nothingness in itself and of the selfawareness of true self and the world by eternal object which is the idea of the field of absolute nothingness as medium between the field of absolute nothingness and the actual world. The reason being that the "way of walking" on the ground of self-awareness in the field of absolute nothingness, namely reality in itself as "mediation" without medium can be widened and deepened first through a medium like "eternal object" in the contemporary world after WWII and its attendant nuclear contamination. It is required of each of all humankind that each person has not only internal sinconsciousness, but also and always and simultaneously an external sin-consciousness of the world, since world is built into each person at the crossroads where the horizontal dimension of the world meets the vertical dimension of each person; the world, world history, is built not only in the world, but also always simultaneously in each individual of humankind. It is, of course, also necessary that the way of walking by the medium of eternal object on the ground of feeling is ultimately widened and deepened for all humankind. However, the relation between "the way of walking" by mediumless mediation and medium as eternal object seems to go on in circles.

In any case, religion in the contemporary world must have both sides, mediumless mediation by reality in itself and a medium-like eternal object between the field of absolute nothingness as reality in itself and medium-like eternal object between the field of absolute nothingness as reality in itself and the actual world going on in the 
crossing point between the horizontal way of the world with the vertical way of each individual.

So far as the identity of self and world in each individual can be first realized not only in salvation, as the true awareness of the true self, but also always and simultaneously in salvation as selfawareness of the world in the true self, the medium of the eternal object is helpful for the "way of walking" in all religions. This true way of walking in all religions can be defined by the way of walking by the world, but the way of walking by the world can be at the same time inversely defined by the way of walking by the self, "the way of mediation without medium by reality in itself" in Nishida, and this can be widened and deepened by various mediums as ideas. After dropping nuclear bombs, after nuclear and hydrogen weapons testing, after accidents at nuclear power plants it seems to be unconditionally necessary that there should be, between actual world and true reality in itself as the field of absolute nothingness, the way of medium, or various kinds of media, like the eternal object, which can convey not only internal sin-consciousness by each self, but also always simultaneously external sin-consciousness by the world in each true self.

Superficially it would seem that Whiteheadian philosophy from the actual world to the harmonious world with truth, beauty, adventure, and peace, and Nishida's philosophy of the field of absolute nothingness as reality in itself to the actual world are developing in opposition. However, in our contemporary world it is sincerely necessary that both directions will be in oneness, in that the way of walking by the world and therefore also by the true self can never be completed owing to nuclear contamination, which decides rise or ruin of the future earth.

Since Buddhism and Christianity were organized, the problem of internal sin-consciousness in each person has always been one of the central problems of religion. But after the Second World War, religion should positively protect not only each individual but also the world, the future, from nuclear contamination and its pernicious influence, with sharpened evil- and sin-consciousness in the world, in that each of us experiences radioactivity and the genetic damage it causes. While self-awareness in religion consists of the self-awareness of each self and world, sin-consciousness in 
religion consists of also internal and at the same time external sinconsciousness, although the latter exists also in each individual. Otherwise, namely without sin -consciousness of the world, religion can never transform society.

\section{References}

Buber, M. (1994). Gottesfinsternis- mit einer entgegnung von c.g.jung. Stuttgart: Lambert Schneider Verlag.

Hanaoka, E. (2008). Zen and Christianity. from the standpoint of absolute nothingness. Maruzen Press.

Hanaoka, E. (2010). Zen and Christianity- kirisutokyo-to-bukkyo-o megutte (The Origin of Zen and Christianity-Zen as the manifestation of the original life), Tozai-reisei-bunko 4. Nunburusha-Press.

Hanaoka, E. (September 2010). The problem of environment and naturethrough the philosophy of A. N. Whitehead and Nishida. Process Thought, 5. The Japan Society for Process Studies.

Hisamatsus, S. (1976) Hisamatsu Shinichi's Works.(3), Risosha Press.

Jonas, H. (1979). Das prinzip für die technologische zivilization. Frankfurt am Main : Insel Verlag.

Nishida, K. Nishida's works, (Bd. 11, Last Writings). Iwanami Press.

Nishida, K. (1965). Nishida's works. (Band 10). Iwanami Press.

Nishida, K. (1987). Last writings-nothingness and the religious worldview. trans. David A. Dilworth, Honolulu: University of Hawaii Press.

Nishida, K. (1990). An Inquiry into the good, (tran) Masao Abe and Christopher Ives. New Haven and London: Yale University Press.

On Tillich's. (1956). Ultimate concern. Systematische theologie, Evangelisches Verlagswerk, Stuttgart . Band I.

Whitehead, A. N. (1929). Process and reality, corrected edition, (ed). David R. Griffin and D. W Sherburne, New York: The Free Press, Macmillan Publishers.

Whitehead, A. N. (1967). Adventures of ideas. London: Collier Macmillan Publishers.

Whitehead, A. N. (2005). Religion in the making. New York: Fordham University Press. 